\title{
Atraumatic aortic rupture as a consequence of penetrating aortic atherosclerotic ulcer rupture
}

\author{
Zain Sharif, Cian O'Carroll-Lolait, David Moore, Bryan Loo
}

Cardiology Department, Tallaght Hospital, Dublin, Ireland

\section{Correspondence to}

Dr Zain Sharif, zainsharif@rcsi.ie

Accepted 6 May 2018

\section{DESCRIPTION}

A woman in her 70 s with rheumatoid arthritis presented to the emergency department with progressive dysnoea and sharp chest pain radiating to her back over the preceding day. No recent thoracic trauma was recollected. Examination demonstrated frailty, hypotension with a mean arterial pressure of 50, normal heart sounds and reduced air entry at the right base on ausculation of lung fields. No radial asymetry or pulsus paradoxus was present.

An ECG demonstrated left bundle-branch block. Twenty-four hour high sensitivity troponin was negative. Serial arterial gas haemoglobin within $30 \mathrm{~min}$ demonstrated haemoglobin drop from $10.8 \mathrm{~g} / \mathrm{dL}$ to $8 \mathrm{~g} / \mathrm{dL}$. Chest X-ray demonstrated widened mediastinum, appearing wider than prior imaging a year previously. Emergency echocardiogram revealed a $1 \mathrm{~cm}$ pericardial effusion with fibrin deposition extending $1.8 \mathrm{~cm}$ anteriorly. No diastolic ventricular collapse or respiratory variation in transmitral flow was evident to suggest pericardial tamponade.

CT thoracic aortogram (figures 1 and 2) demonstrated a collection of acute blood measuring up to 5.0 by 3.8 by $6.0 \mathrm{~cm}$ inferior to the aortic arch, immediately distal to the subclavian artery origin, exerting mass effect on the pulmonary trunk. Moderate right-sided haemothorax was noted. The great vessels and pericardium were surrounded by complex mediastinal fluid appearing haemorrhagic. A partially opacified fusiform infrarenal abdominal aortic aneurysm was seen, without evidence of acute rupture.

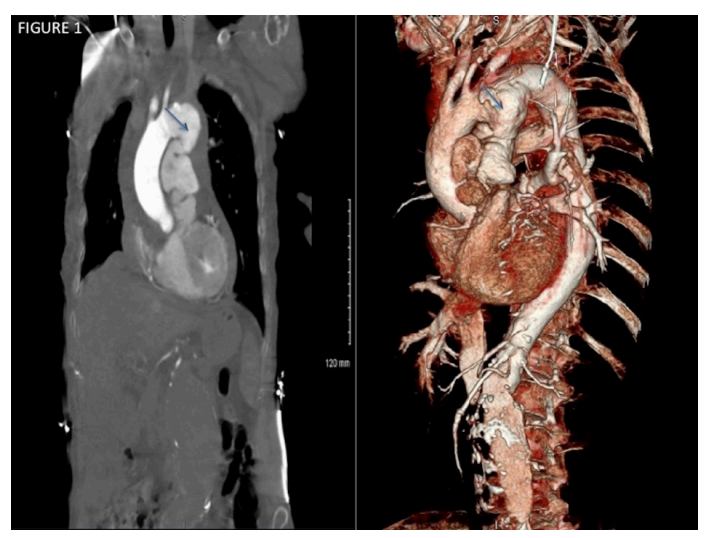

Figure $1 \mathrm{CT}$ aortogram; blue arrow denotes site of aortic rupture. Left: coronal plane; right: 3D reconstruction.

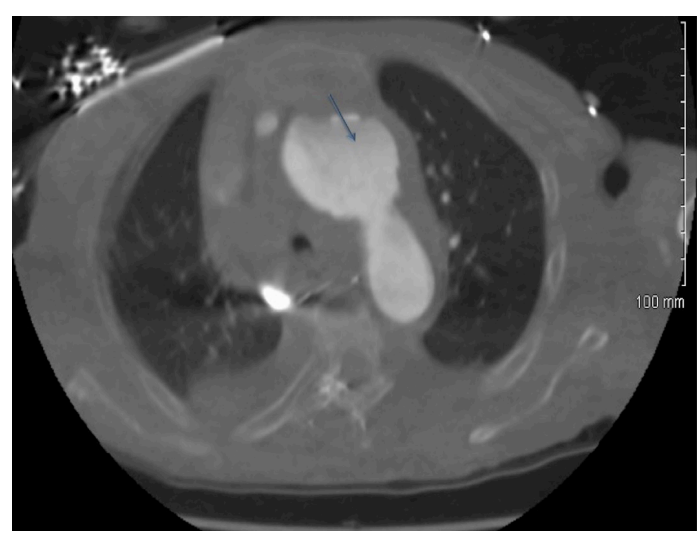

Figure 2 CT aortogram; blue arrow denotes site of aortic rupture. Axial plane.

Deterioration into Pulseless Electrical Activity (PEA) arrest occurred on return from the scanner with unsuccessful resuscitation. Postmortem revealed severe atherosclerosis and pseudoaneurym at an exit point of the aorta suggestive of a ruptured penetrating aortic ulcer (PAU).

Transmural aortic rupture in areas of severely atherosclerotic changes originating from PAUs has been described. ${ }^{1}$ This rare phenomenon is usually lethal when it occurs. ${ }^{2}$ Shennan first described PAU of the thoracic aorta in $1934^{3}$ with his observations added to by Stanson et al in 1986. ${ }^{4}$ The pathology described by these authors is felt to be a progression of the atherosclerotic process where ulceration prenetrates through the internal elastic lamina and extends into the media. Extension of possible haematoma formation along the media can, in some cases, stretch aortic adventitia with resultant saccular pseudoaneurysm formation. ${ }^{5}$ This process can lead to transmural aortic rupture. ${ }^{1}$ The postmortem pathological findings in our case were compatible with the probability of such a process. PAUs are most frequently located in the middle and descending thoracic aorta ${ }^{4}{ }^{6}$ rarely seen in the ascending aorta, with multiple localisations seen quite frequently. ${ }^{7}$ These ulcers usually remain clinically silent until rupture occurs at which time diagnosis is ordinarily made. ${ }^{8}$ Emergency intervention where PAU is complicated by aneurysm expansion, rupture, embolic symptoms or uncontrolled pain is advocated, ${ }^{1}$ whether with surgery or endovascular graft, and can be successful if pathology is identified early and before unstable deterioration. $^{89}$ 


\section{Learning points}

Aortic rupture without preceding trauma is rare but is usually lethal when it occurs.

- This case demonstrates that the vital need for awareness of aortic pathology, early use and accurate interpretation of CT aortogram is paramount.

- Penetrating aortic ulcer (PAU) can be a consequence of severe atherosclerosis and can evolve to transmural rupture. Awareness of PAU within the spectrum of acute aortic syndromes is paramount.

Contributors ZS wrote manuscript and was involved in the diagnosis and management of the case. He also reviewed the literature and drafted the manuscript. $\mathrm{CO}-\mathrm{L}$ was also involved in the management of this patient. DM and BL reviewed the draft and provided consultant overview of the case.

Funding The authors have not declared a specific grant for this research from any funding agency in the public, commercial or not-for-profit sectors.

Competing interests None declared.

Patient consent Not required.
Provenance and peer review Not commissioned; externally peer reviewed.

(C) BMJ Publishing Group Ltd (unless otherwise stated in the text of the article) 2018. All rights reserved. No commercial use is permitted unless otherwise expressly granted.

\section{REFERENCES}

1 Coady MA, Rizzo JA, Elefteriades JA. Pathologic variants of thoracic aortic dissections. Penetrating atherosclerotic ulcers and intramural hematomas. Cardiol Clin 1999:17:637-57.

2 Shennan T. Dissecting aneurysms. Medical Research Council, special report series no 193. London: Her Majesty's Stationery Office, 1934.

3 Stanson AW, Kazmier FJ, Hollier LH, et al. Penetrating atherosclerotic ulcers of the thoracic aorta: natural history and clinicopathologic correlations. Ann Vasc Surg 1986;1:15-23.

4 Troxler M, Mavor Al, Homer-Vanniasinkam S. Penetrating atherosclerotic ulcers of the aorta. Br J Surg 2001;88:1169-77.

5 Lee S, Cho SH. Huge ascending aortic pseudoaneurysm. Tex Heart Inst J 2005;32:235-7.

6 Sundt TM. Intramural hematoma and penetrating atherosclerotic ulcer of the aorta. Ann Thorac Surg 2007;83:S835-41.

7 Sako H, Hadama T, Shigemitsu 0, et al. Pinhole rupture of aortic root aneurysm with severe atherosclerotic change. Ann Thorac Surg 2004;77:1075-7.

8 Tsuji Y, Tanaka Y, Kitagawa A, et al. Endovascular stent-graft repair for penetrating atherosclerotic ulcer in the infrarenal abdominal aorta. J Vasc Surg 2003:38:383-8.

9 Liu YH, Ke HY, Lin YC, et al. A penetrating atherosclerotic ulcer rupture in the ascending aorta with hemopericardium: a case report. J Cardiothorac Surg 2016:11:103.

Copyright 2018 BMJ Publishing Group. All rights reserved. For permission to reuse any of this content visit http://group.bmj.com/group/rights-licensing/permissions.

BMJ Case Report Fellows may re-use this article for personal use and teaching without any further permission.

Become a Fellow of BMJ Case Reports today and you can:

- Submit as many cases as you like

- Enjoy fast sympathetic peer review and rapid publication of accepted articles

- Access all the published articles

- Re-use any of the published material for personal use and teaching without further permission

For information on Institutional Fellowships contact consortiasales@bmjgroup.com

Visit casereports.bmj.com for more articles like this and to become a Fellow 